\title{
Strategy for marine ecotourism development based on natural resource management: Case study in Kotania Bay, Western Seram District, Maluku, Indonesia
}

\author{
HENDERINA LELLOLTERY ${ }^{1}$, MAMAN RUMANTA ${ }^{2, \boldsymbol{v}}$, RONY MARSYAL KUNDA ${ }^{3}$ \\ ${ }^{1}$ Department of Forestry, Faculty of Agriculture, Universitas Pattimura. Jl. Ir. Putuhena, Poka, Ambon 97233, Maluku, Indonesia \\ ${ }^{2}$ Program of Biology Education, Faculty of Teacher Training and Education, Universitas Terbuka. Jl. Cabe Raya, Pondok Cabe, Pamulang, Tangerang \\ Selatan 15418, Banten, Indonesia. `email: mamanr@ecampus.ut.ac.id, ronykunda@gmail.com \\ ${ }^{3}$ Department of Biology, Faculty of Mathematics and Natural Sciences, Universitas Pattimura. Jl. Ir. Putuhena, Poka, Ambon 97233, Maluku, Indonesia
}

Manuscript received: 10 February 2021. Revision accepted: 14 April 2021.

\begin{abstract}
Lelloltery H, Rumanta M, Kunda RM. 2021. Strategy for marine ecotourism development based on natural resource management: Case study in Kotania Bay, Western Seram District, Maluku. Nusantara Bioscience 13: 91-99. The study aimed to identify the potential for marine ecotourism in Kotania Bay, and formulated strategies and priorities for developing marine ecotourism in Kotania Bay. Data collection on ecological potential consisted of mangrove and fauna vegetation using the line transect method, while coastal and marine resources included coral reefs and reef fish using the Line Intercept Transect (LIT) method. Development strategies and priorities used the SWOT and AHP methods. The results showed that the potential of coastal natural resources around the Kotania Bay consisted of 12 mangrove species belonging to 7 families with species diversity index 1.76, and dominated by Rhizophora mucronata and Bruguiera cylindrica. The bird species were 33 species belonging to 23 families, with several endemic species such as Philemon subcorniculatus, Eulipoa wallacei, Birgus latro, and Pteropus melanopogon. Potential marine water resources consisted of 45 coral species belonging to 23 genera and 14 families with 10-12 life-forms. The diversity of reef fish species was quite abundant consisting of 129 species from 60 genera and 22 families. The sand beach on Marsegu island is a tourist destination that is demanded by the tourists. SWOT analysis showed that the potential of coastal and marine natural resources in Kotania Bay is very likely to be developed as marine ecotourism.
\end{abstract}

Keywords: Ecotourism, Kotania Bay, priority, strategy

\section{INTRODUCTION}

Maluku is categorized as an archipelago that has 1,450 islands with high natural resources. Most of these islands are small islands that have abundant coastal natural resource potentials such as beautiful beaches, mangrove ecosystems, coral reefs, fishes, seagrass, and various other marine and coastal biota. The resources are very potential to be developed but vulnerable to over-used. Therefore, the right strategy is needed in the development process so that there is no damage to natural resources and it still provides significant benefits to the community and the environment. One alternative that can be considered is through the use of environmental services based on marine ecotourism (Baiquni 2013).

Ecotourism in coastal and marine areas contributes to the economy of local communities and supports conservation and protection actions of coastal and marine ecosystems (Walters and Samways 2001). Efforts to develop marine ecotourism in small islands of Maluku can be done by considering the very abundant potential of natural resources. Baiquni (2013) stated that small islands can be ecotourism destinations since they provide abundant natural resource potential. The concept of ecotourism can broadly minimize negative impacts on the environment, by providing positive experiences to the community and visitors, then contributing to the benefits of economic empowerment to the community (Das and Chatterjee 2015).

One of the ecotourism destinations in Maluku is the Kotania Bay of the West Seram District. Kotania Bay is located among five islands, i.e. Marsegu, Osi, Burung, Buntal, and Tatumba. Marsegu and Osi islands are quite famous tourist destinations. This is due to the coastal natural resources and potential marine in the form of mangrove ecosystems, white sand beaches, coral reefs, reef fish, seagrasses, and various marine biota. These resources can be a potential object and attraction for tourists. The area around Kotania Bay is designated as a marine conservation area with the status of Marsegu Island Nature Tourism Park (Nature Conservation Agency Indonesia, 2014).

The potential of coastal natural resources from the region is not optimally developed for ecotourism activities. This is caused by various factors such as minimal infrastructure and the construction of conventional thinking about the concept and view of optimal uses of the coastal resources. Facts on the ground show that the limited government support can be seen from the lack of regulations regarding tourism activities. Lack of regulation greatly impacts the development process of ecotourism in Kotania Bay is getting slower. To develop the potential of 
these natural resources, a comprehensive analysis is required by developing a regional development strategy that takes into account the characteristics of the area and the conditions of the community. For this reason, comprehensive studies are very important to be carried out to understand development strategies that will become an empirical basis for a policy design of sustainable ecotourism. This study aims to identify the potential of ecotourism in the Bay of Kotania, and to formulate a strategy and priority scale for ecotourism-based development.

\section{MATERIALS AND METHODS}

\section{Study area}

The study was conducted at Kotania Bay areas in Marsegu and Osi Islands, Western Seram District, Maluku for six months from June to December 2019. The locations of sampling sites are shown in Figure 1.

\section{Data collection}

Data collection consisted of primary and secondary data. Primary data collection was done through field observations and interviews, secondary data was collected through literature studies including data on marine conditions, the physical condition of the region, regional statistical data, and other supporting data obtained from books, journals, and reports related to the study. Data collection by interview method was carried out for all stakeholders involved including surrounding communities, area managers, and local governments. The interview method was conducted in a structured manner with a questionnaire. Interviews were conducted with people directly involved in ecotourism activities in two sample villages, i.e. Pelita Jaya and Osi Island hamlet. The number of respondents interviewed was 30 peoples for each village.

Data collection of coral reefs and fish used the line intercept transect (LIT) method (English et al. 1997) with observations at six stations. Coral benthic was done by recording all components along the 50 meters coastline. A description of the morphology of coral communities was carried out in the life-form category. Mangrove and other fauna data collection used the line transect method, by making four transects with a length of 500 meters each transect. Potential flora and fauna data, observed in the same path included species, number of species, species diversity, and status of species.

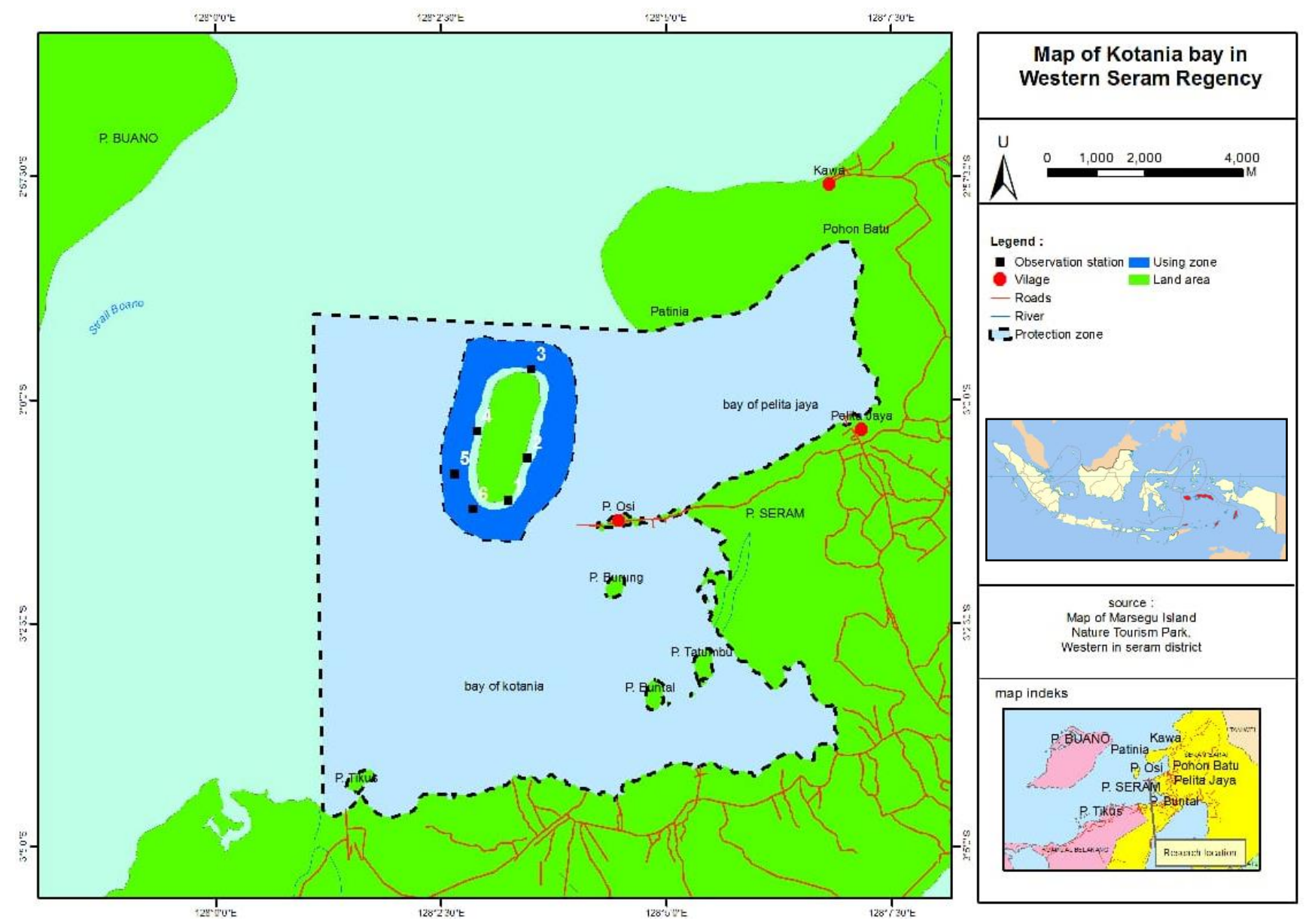

Figure 1. The locations of sampling sites in Kotania Bay, Maluku, Indonesia 
Observations of the coastal characteristics were carried out on several parameters related to the suitability of coastal tourism following Yulianda (2007) which was modified for the study including the types of beach, coastal land cover, water bottom materials, dangerous biota (carried out by visual observation), and snorkeling around the coast. Measuring the width of the beach was using roll meters, while the availability of freshwater was measured based on the distance of the source of clean water to the location where ecotourism activities are carried out.

\section{Data analysis}

SWOT analysis was carried out for strategic factors that affect tourism activities, i.e. internal and external factors. Internal factors analysis was carried out using the Internal Factor Analysis Strategy (IFAS), while external factors used the External Factor Analysis Strategy (EFAS). Based on the IFAS and EFAS matrices then a SWOT matrix was made (Table 1). From each SWOT element, some elements which have the highest or most strategic influence were chosen. Analytic Hierarchy Process (AHP), is a method of decision making with multiple criteria developed by Saaty (1993). To determine the priority of ecotourism development programs, and evaluation of ecological, economic, social, cultural, and institutional aspects was based on internal and external factors that have an important value on the ecotourism development strategy around the area. The selection of respondents was based on a purposive sampling technique with the consideration that the respondent can make policy and provide input to policymakers (government, private sector, and local communities). The AHP analysis uses analysis tools in the form of Expert Choice software version 11.

\section{RESULTS AND DISCUSSION}

\section{Potential of natural resources as marine ecotourism objects}

The coastal and marine natural resources in Kotania Bay, including the potential of coral reefs, reef fish, mangrove ecosystems, and various types of wildlife, and white sand beaches as tourist destinations are potential as marine ecotourism objects and are in demand by the tourists.

\section{Potential of mangroves and wildlife}

The identification of mangrove ecosystems around Marsegu island found 12 species belonging to 7 families, dominated by the Rhizophoraceae family, some species within the family were Rhizophora mucronata, Bruguiera gymnorrhiza, and B. cylindrical, with the diversity index 1.76 , and classified as medium category. This showed that mangroves in the Marsegu island region are in a "stable" condition. Considering the potential resources, the mangrove vegetation can be further developed as an object of tourist destination. Ecotourism activities can be carried out through the guidance of the interpretation lane. The lane interpretation is developed to provide conservation education for visitors to know mangrove species so that it becomes an educational mode. Fandeli and Muckhlison (2009) stated that the observation of flora is a great experience for the visitors to learn about the flora and climatic conditions that affect the ecosystem. The development of interpretation lane in Osi Island was a mangrove bridge with a length of $1.2 \mathrm{~km}$ and width of 2 meters, while Marsegu island was provided through the lane of mangrove forest in the south Kotania Bay and Pelita Jaya Bay.

Mangrove observation was carried out in conjunction with wild animal observation. The observation of animals found 33 bird species belonging to 23 families, consisted of four species of limited distribution (BST), one endemic bird species of Seram island, P. subcorniculatus, and one endangered bird species, E. wallacei. Likewise shorebirds such as Egretta garzetta, Egretta sacra, Ducula bicolor, and Pteropus melanopogon. In addition to the bird species, there are mammal species (Pteropus melanopogon) that make the mangrove ecosystem as their habitat. The daily activity of these species looks like a tourist attraction. Another interesting fauna is Birgus latro which can be found in several places on Osi and Marsegu islands, and various species of wild animals make the mangrove forest as their habitat.

Table 1. SWOT analysis matrix

\begin{tabular}{lll}
\hline Internal Factors (IFAS) & $\begin{array}{l}\text { STRENGTH (S) } \\
\text { Determined 5-10 internal strength factors }\end{array}$ & $\begin{array}{l}\text { WEAKNESS (W) } \\
\text { Determined 5-10 internal weakness factors }\end{array}$ \\
$\begin{array}{l}\text { External Factors } \\
\text { (EFAS) }\end{array}$ & $\begin{array}{l}\text { STRATEGY (S-O) } \\
\text { Strategies that use power to take } \\
\text { advantage of opportunities }\end{array}$ & $\begin{array}{l}\text { STRATEGY (W-O) } \\
\text { Strategies that minimize weaknesses } \\
\text { to take advantage of opportunities }\end{array}$ \\
$\begin{array}{l}\text { Determined 5-10 external opportunity } \\
\text { factors }\end{array}$ & $\begin{array}{l}\text { STRATEGY (S-T) } \\
\text { Strategies that use power to overcome } \\
\text { threats }\end{array}$ & $\begin{array}{l}\text { STRATEGY (W-O) } \\
\text { Strategies that minimize weaknesses to } \\
\text { take advantage of opportunities }\end{array}$ \\
$\begin{array}{l}\text { THREATS (T) } \\
\text { Determined 5-10 external threat factors }\end{array}$ & & \\
\hline
\end{tabular}


Idajati et al. (2016) stated that the potential of mangrove forests with the wild animals can be developed into mangrove ecotourism by involving the participation of local communities. Besides, Rhormens et al. (2017) stated that mangrove ecosystems in protected areas can be one of the objects to promote the ecotourism area. This indicated that the diversity of mangroves and fauna can be an ecotourism attraction. Furthermore, Gunn (1994) reported that the diversity of flora and fauna which are endemic and frequently found in tropical regions can be the object of ecotourism activities.

\section{Potential of coral reefs and coral fish}

There were 45 species of coral reefs belonging to 23 genera and 14 families. Closure of coral reefs found in the form of hard coral included acropora and non-acropora, soft coral, dead coral (dead coral algae), algae, sponges, other biotas (OT), and abiotic. Hard coral dominates coral cover with a percentage of $69.86 \%$. Based on the value of live coral cover, it can be seen that the health level of coral ecosystems is in a good category, while the number of lifeforms identified was 12 . The diversity of coral types found around the marine area of Marsegu Island is supported by the marine physical condition including temperature, salinity, chlorophyll-a, ocean current, and brightness level with values of $28.66{ }^{\circ} \mathrm{C}, 34.10 \%$ o, 0,31 $\mathrm{ppb}, 0.167 \mathrm{~m} / \mathrm{sec}$, and $80 \%$ respectively.

The types of corals found in the Kotania Bay have branched growth forms (ACB), such as table (ACT), submassive (ACS) with beautiful and attractive colors to tourists, especially foreign tourists for snorkeling and diving activities. This is in line with Lelloltery et al. (2018a) stated that the form of coral growth, coral species both acropora, non-acropora, soft coral with interesting shapes and colors is a tourist attraction. Burke et al. (2011) stated that diving activity is the most popular tourist activity because they can enjoy the beauty of coral reefs in their habitat. Supriharyono (2007) stated that coral reefs have a beauty value that cannot be doubted because of the mainstay of marine tourism.

Based on the observations of reef fish, 146 species were found belonging to 64 genera and 21 families. Fish species found, based on their function and role, consisted of 16 species of fish (10.95\%), 81 species of major fish $(55.48 \%)$, and 49 species of target fish $(33.56 \%)$. Fish species found have interesting shapes and colors. The existence of fish showed that the condition of the coral reef is categorized as good (Latuconsina 2015). One species of fish whose status is threatened in nature is Cheilinus undulatus (IUCN, 1994). The existence of this fish is an attraction for the tourists who want to see this fish species directly in their habitat. This finding is following Wabnitz et al. (2017) who stated that the protection of areas that become habitats of endangered species is needed to minimize the loss of endemic fish species in their natural habitat.

\section{White sand beach}

The beach which is dominated by white sand can only be found on Marsegu island from east to north with a beach length of $1.68 \mathrm{~km}$ and is currently a location that is in demand by both domestic and foreign tourists. The beach's general characteristics are 0-3 meters of depths, 20-30 meters of widths when the low tide, bottom marine dominated by sand, and the beach slope is around $7^{\circ}$. Coastal land cover is dominated by forest with dominant species are Pongamia pinnata, Hibiscus tiliaceus, Terminalia catappa, and the northern is dominated by shrubs.

The existence of two wells for providing clean water isa little bit far, i.e. about 800 meters. The availability of clean water is one of the obstacles in the development of coastal tourism in the area, so that supporting facilities are needed to meet the needs of clean water for the visitors. The beach characteristics, white sand, on Marsegu Island are very suitable for ecotourism activities (Lelloltery et al. 2016).

\section{Socio-economic of the local community}

The local people who live around Kotania Bay belong to the coastal community of the Western Seram District. They are generally migrants and natives of Seram Island. The migrants come from Buton Island, Southeast Sulawesi Province, but have inhabited the coastal region of the Seram island since their ancestors. Their main livelihood is fishermen, so they use marine resources as a source of livelihood. To fulfill their basic needs, the community carries out seaweed farming and fish ponds. The activities of catching fish and utilizing marine resources cannot be separated from the lives of local communities. Nikijuluw (2003) stated that coastal communities have a high dependency and consumption of natural resources. The communities are having a low level of education (elementary school), and their livelihood consists of fishermen $(53 \%)$, entrepreneurs $26.6 \%$, and the rest are civil servants or police, and the army. Based on the age level, it is generally in the productive age $(86.66 \%)$. This productive age is related to the potential of the workforce in the tourist area.

The participation of the community is limited to providing services such as accommodation, consumption, transportation, and tour guides (Lelloltery et al. 2018b). Their involvement is still passive, has business planning, and depends on the demand of visitors. Though it provides employment, business opportunities, additional income to the local communities. Damanik (2013) stated that ecotourism on small islands creates diverse opportunities, i.e. employment, for the communities. The creation of employment from ecotourism activities can improve economic welfare by forming a symbiotic mutualism between local communities and natural areas (Stronza and Gordillo 2008).

Community participation in providing services, i.e. shopping activities, to the visitors can provide economic benefits. For example, the total expenditure of foreign tourists is an average of IDR 979,000/day with a standard deviation of IDR 276,036/day. This value is quite efficient for the local communities. Lelloltery (2018b) stated that the service activities in supporting ecotourism have contributed to the income of the local communities. 


\section{Condition of facilities and accessibility at tourist area}

Tourist facilities are available on the Osi island, i.e. accommodation facilities (homestays), transportation (motorcycle, cars, and motorboats), restaurants, shops, and stalls. The facilities are commonly owned by the local communities and managed independently to support ecotourism activities. Abdulhaji and Yusuf (2016) stated that the facilities available at the tourist area will encourage the visitors to come again and enjoy the attractions. To date, the condition of tourist facilities faces several obstacles including the limited number of sea and land transportation, unskilled human resources, and efforts to increase human resources so far not yet intensively carried out.

To date, access to tourist areas can be reached by using sea and land transportation. The road trip from Ambon city takes an hour to the seaport in the Liang village, then continued by ferry (ASDP) for 1.5 to 2 hours to the Waipirit seaport in Western Seram District. From the capital city of West Seram District take the car or motorbike for two hours to the ecotourism area. The visitors can enjoy along the mangrove forest, it can be done on foot or using a motorbike with a travel time of about 20 to 30 minutes. To explore the marine or visit the small islands and white sand beaches on Marsegu island, can be reached by traditional motorboats approximately 15 to 30 minutes.

\section{Ecotourism development strategy}

Activities to develop an area require strategic planning and study of the strategic factors of an organization which includes strengths, weaknesses, opportunities, and threats (Rangkuti 2002). Strategic factors in developing ecotourism in the Kotania Bay area were formulated based on a SWOT analysis. Based on these strategic factors, strategies and alternative policies were formulated in the development of ecotourism. Development policy priorities were carried out by AHP analysis. The analysis of strategic factors (internal and external factors) and the determination of policy priorities are presented as follows:

\section{Internal factors}

The values of strategic factors as a component of strengths and weaknesses in the development of ecotourism (Table 2).

\section{External factors}

The value of strategic factors as a component of opportunities and threats in the development of Ecotourism is provided in Table 3.

Based on Tables 2 and 3, the IFAS values for internal factors (the difference between Strength and Weakness values) was 0.271, while the EFAS values for external factors (the difference between the Opportunity and Threat values) was 0.11 . The IFAS values obtained are positive which means cumulatively the strength factor is more dominant than weakness, while the EFAS values are negative which means the opportunity factor is smaller than the threat. Referring to the IFAS and EFAS values, the SPACE matrix and ecotourism mapping positions were in quadrant II, the strategy that must be applied is the diversification strategy (ST). The results of the analysis of strategic factors that influence the development of ecotourism are summarized in Table 4. Based on the matrix, there are four alternative strategies to develop ecotourism activities in Kotania Bay, but the results of the analysis of strategic factors revealed that the development should apply a diversification strategy (ST).

The results of the SWOT analysis showed that strength factors included the diversity of coastal and marine resources, with endemic species. Natural resources supported by the local wisdom of the community are a major force for the region to be developed. Support and community participation are factors that influence the success of the development of an area to the fullest. Coria and Calfucura (2012) reported that collaboration and community participation are keys to the success of ecotourism. In addition to that government support, high accessibility to ecotourism areas, and positive perceptions from the local communities are opportunities to increase efforts to the development of ecotourism areas.

Table 2. Internal factors in developing ecotourism potential

\begin{tabular}{|c|c|c|c|c|}
\hline \multicolumn{2}{|c|}{ Factors } & Quality & Score & Value of influence \\
\hline \multicolumn{5}{|c|}{ Strength Factors } \\
\hline 1. & $\begin{array}{l}\text { Potential aquatic resources in the form of coral reefs, reef fish, and other } \\
\text { biota as conservation areas with small island ecosystems }\end{array}$ & 0.101 & 4 & 0.404 \\
\hline 2. & Having specific mangrove ecosystem and endemic fauna species & 0.094 & 3 & 0.282 \\
\hline 3. & Having the diversity of objects and tourist attractions & 0.085 & 3 & 0.255 \\
\hline 4. & Having the culture and local wisdom of a typical coastal community & 0.084 & 3 & 0.249 \\
\hline \multirow[t]{2}{*}{5.} & Support and participation of local communities & 0.085 & 3 & 0.255 \\
\hline & Total & & & 1.445 \\
\hline \multicolumn{5}{|c|}{ Weakness Factors } \\
\hline 1. & Limited supervision & 0.08 & 2 & 0.16 \\
\hline 2. & Limited supporting facilities and infrastructure within the region & 0.101 & 2 & 0.30 \\
\hline 3. & Promotion and publication of the area have not been done intensively & 0.090 & 2 & 0.270 \\
\hline 4. & Limited human resources both in quantity and quality & 0.091 & 2 & 0.27 \\
\hline \multirow[t]{2}{*}{5.} & Regional boundary arrangement has not been carried out optimally & 0.09 & 1 & 0.17 \\
\hline & Total & & & 1.174 \\
\hline
\end{tabular}


Table 3. External factors in developing ecotourism potential

\begin{tabular}{|c|c|c|c|c|}
\hline \multicolumn{2}{|c|}{ Factors } & Quality & Score & Value of influence \\
\hline \multicolumn{5}{|c|}{ Opportunity } \\
\hline 1. & Support of government of Western Seram District for the development of ecotourism & 0.101 & 2 & 0.202 \\
\hline 2. & $\begin{array}{l}\text { Positive perceptions from the local communities and visitors related to efforts to } \\
\text { develop ecotourism }\end{array}$ & 0.085 & 3 & 0.255 \\
\hline 3. & Easy accessibility & 0.099 & 3 & 0.297 \\
\hline 4. & The trend of tourist visits is increasing from year to year & 0.101 & 3 & 0.303 \\
\hline \multirow[t]{2}{*}{5.} & The tourism potential can be a tour package in Western Seram District & 0.099 & 2 & 0.198 \\
\hline & Total & & & 1.255 \\
\hline \multicolumn{5}{|c|}{ Threat } \\
\hline $\begin{array}{ll}1 . \\
2 .\end{array}$ & $\begin{array}{l}\text { There is still environmental damage due to marine and coastal pollution activities } \\
\text { Logging of mangrove forests }\end{array}$ & 0.135 & 3 & 0.405 \\
\hline 3 . & $\begin{array}{l}\text { Local communities knowledge is still minimal about the conservation of natural } \\
\text { resources }\end{array}$ & 0.106 & 3 & 0.314 \\
\hline 4. & The dependence of local communities is still high on natural resources & 0.084 & 2 & 0.168 \\
\hline \multirow[t]{2}{*}{5.} & Limited cooperation and coordination between stakeholders & 0.102 & 2 & 0.204 \\
\hline & Total & & & 1.365 \\
\hline
\end{tabular}

Table 4. Matrix of SWOT analysis to develop ecotourism based on natural resource management

\begin{tabular}{|c|c|c|}
\hline External & 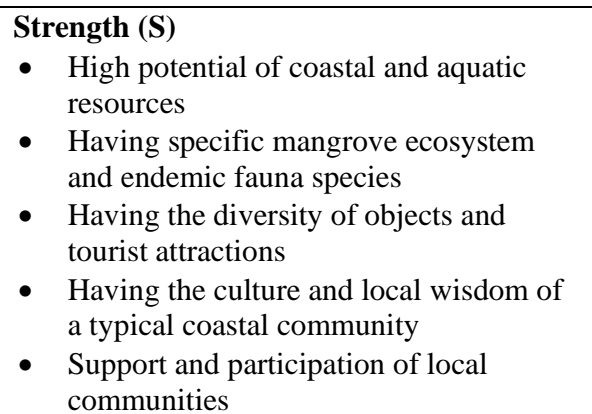 & $\begin{array}{l}\text { Weakness }(\mathbf{W}) \\
\text { - } \quad \text { Limited supervision } \\
\text { - } \quad \text { Limited supporting facilities and } \\
\text { infrastructure within the region } \\
\text { - } \quad \text { Promotion and publication of the area } \\
\text { have not been done intensively } \\
\text { - } \quad \text { Limited human resources both in } \\
\text { quantity and quality } \\
\text { - Regional boundary arrangement has not } \\
\text { been carried out optimally }\end{array}$ \\
\hline $\begin{array}{l}\text { Opportunity (O) } \\
\text { - The support of the Local } \\
\text { Government of Western Seram } \\
\text { District for the development of } \\
\text { ecotourism in the Regional } \\
\text { Medium-Term Development Plan } \\
\text { 2017-2022 } \\
\text { - Positive perceptions from the local } \\
\text { communities and visitors related to } \\
\text { efforts to develop ecotourism } \\
\text { - Easy accessibility } \\
\text { The trend of tourist visits is } \\
\text { increasing from year to year } \\
\text { The tourism potential can be a tour } \\
\text { package in Western Seram District }\end{array}$ & $\begin{array}{l}\text { Strategy (SO) } \\
\text { - Developing the potential of coastal and } \\
\text { marine resources including coral reefs, } \\
\text { reef fish, and marine biota as a special } \\
\text { marine ecotourism attraction for beach } \\
\text { tourism with snorkeling, diving as the } \\
\text { main attractions } \\
\text { - Improve facilities or infrastructure to the } \\
\text { ecotourism area } \\
\text { - Using the potential of marine resources, } \\
\text { flora and fauna, and local wisdom of the } \\
\text { community into a package tour } \\
\text { - Promote the potential of ecotourism } \\
\text { through printed and electronic media. } \\
\text { Improving the quality of tourism } \\
\text { products by involving local communities }\end{array}$ & $\begin{array}{l}\text { Strategy (WO) } \\
\text { - Regional arrangement so that it becomes } \\
\text { more accountable } \\
\text { - Increasing intensive supervision of } \\
\text { ecotourism areas with the support of } \\
\text { local communities } \\
\text { - Providing Facilities and Infrastructure } \\
\text { - Intensifying promotion and publication } \\
\text { activities } \\
\text { - Improve the quality of human resources } \\
\text { - Community empowerment through the } \\
\text { provision of business capital and the } \\
\text { establishment of tourism aware groups }\end{array}$ \\
\hline $\begin{array}{l}\text { Threat }(\mathbf{T}) \\
\text { - To date, there is still environmental } \\
\text { damage due to marine and coastal } \\
\text { pollution activities as well as } \\
\text { logging of mangrove forests } \\
\text { - The knowledge of local } \\
\text { communities about natural resource } \\
\text { conservation is categorized as low } \\
\text { - Communities dependence on } \\
\text { coastal natural resources is } \\
\text { categorized as high } \\
\text { - Cooperation and coordination } \\
\text { between stakeholders is limited }\end{array}$ & $\begin{array}{l}\text { Strategy (ST) } \\
\text { - Developing the potential of coastal and } \\
\text { marine natural resources sustainably } \\
\text { - Increase participation and empowerment } \\
\text { of coastal communities } \\
\text { - Promoting and educating conservation to } \\
\text { local communities } \\
\text { - Developing partnerships among } \\
\text { stakeholders in the effort to manage } \\
\text { attractions, accessibility, and amenities } \\
\text { area } \\
\text { - Increasing the area's security by } \\
\text { involving local communities, adding } \\
\text { security personnel, and law enforcement }\end{array}$ & $\begin{array}{l}\text { Strategy (WT) } \\
\text { - Increasing stakeholder cooperation in } \\
\text { efforts to safeguard the area } \\
\text { - Strengthen the role and function of local } \\
\text { government and local communities } \\
\text { - Involve non-governmental organization } \\
\text { (NGO) and the private sector in the } \\
\text { development of ecotourism } \\
\text { - Increasing the number and quality of } \\
\text { human resources through training on } \\
\text { tourism, environmental conservation in } \\
\text { supporting the ability of management, } \\
\text { the community, and the business world } \\
\text { in the development of ecotourism }\end{array}$ \\
\hline
\end{tabular}


Other factors which become obstacles in the development of ecotourism are limited infrastructure and human resources, as well as low promotional activities. This condition is caused by the limited involvement of stakeholders, especially in providing infrastructure. Reihanian et al. (2012) stated that the lack of supporting infrastructure may cause ecotourism activities unsustainably. Besides, Das and Chatterjee (2015) asserted that improving infrastructure can sustainably affect ecotourism activities, and improve the living standards of local communities. Besides, there are still threats in the area in the form of fishing activities by applying destructive principles and logging activities to mangrove forests. This condition occurs due to very high community dependence on coastal and marine resources. Emmanuel and Spence (2009) reported that coastal and marine communities are highly dependent on marine and coastal resources. This causes utilization activities that are not environmentally friendly.

The results of the SWOT analysis showed that threats still outweigh opportunities in the region so that strategies are needed to overcome threats by optimizing the strength of the region. The involvement of local communities in the region and the economic benefits received by the local community from ecotourism activities are expected to be a solution to overcome the problem of community dependence on coastal and marine resources. Ghorbani et al. (2015) asserted that the collaboration and participation of local communities are the keys to guarantee sustainable ecotourism. The results of the analysis showed that ecotourism activities have not been achieved well in Kotania Bay, so that the diversification strategy obtained from the SWOT results provides policy direction for regional development.

The diversification strategy (ST) is described in several alternative activities, i.e. (i) developing the potential of coastal and marine natural resources in a sustainable manner, (ii) encouraging participation and empowering coastal communities, (iii) promoting conservation education to the local communities, (iv) developing partnerships among stakeholders in the effort to manage the attractions, accessibility, and amenity of the area, (v) increase the security of the area by involving local communities, law enforcement, and strict regulations regarding the management and development of ecotourism.

\section{Priority ecotourism development in Kotania Bay}

Ecotourism development strategies based on SWOT analysis cannot be implemented at the same time due to limited funds, time, and human resources, so that it is necessary to determine priority programs that must be implemented. The determination of priority programs for the development of ecotourism areas is carried out by taking into account the factors involved, so there must be Analytic Hierarchy Process (AHP). The results of the pairwise comparison analysis related to the priority of ecotourism development are shown in Figure 2. The priority of developing ecotourism is implemented in the form of implementing activities (Table 5).

The results of AHP analysis showed that integrated natural resource development is a priority of ecotourism development activities, which are implemented through development activities (Table 5). The priority from developing ecotourism is based on the Block system. This is intended to map the area so that it is developed following the functions and potential possessed. The establishment of these blocks facilitates supervision to minimize activities that are destructive and in turn increase protection of natural resources.

Besides, the second priority is the participation and empowerment of coastal communities. This is intended to increase the active role of the local communities in ecotourism activities because it has an impact on improving the community economy. This condition can be a useful tool to minimize community dependence on resources due to the availability of jobs. Damanik (2006) reported that community participation in ecotourism activities can provide benefits to local communities individually or collectively as well as direct conservation benefits for ecosystems.

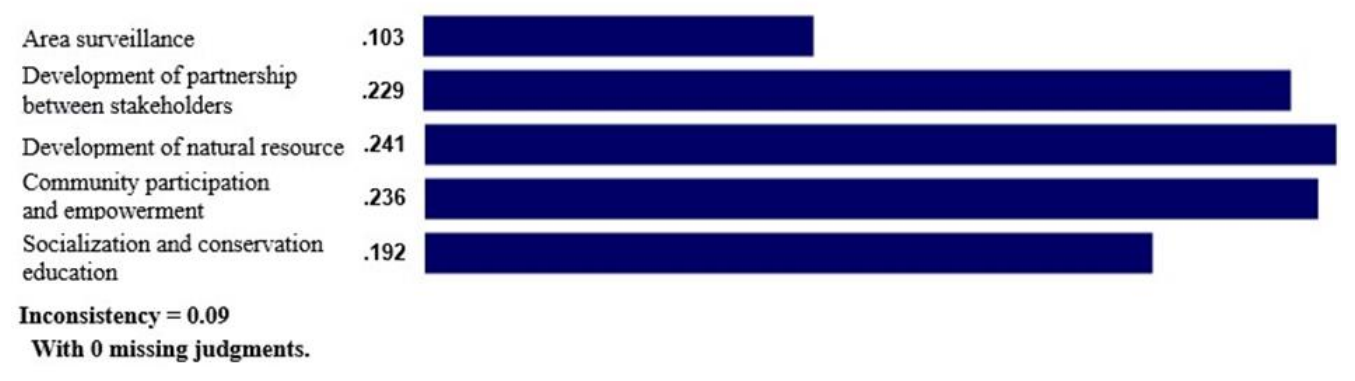

Figure 2. Priority of ecotourism development programs 
Table 5. Priority of ecotourism development activities

\begin{tabular}{|c|c|c|}
\hline No. & Priority development & Development activities \\
\hline 1 & $\begin{array}{l}\text { Development of potential ecotourism } \\
\text { objects sustainably }\end{array}$ & $\begin{array}{l}\text { Development with a block system } \\
\text { Marine ecotourism block (beach, snorkeling, and diving) } \\
\text { Mangrove ecotourism block (Path of interpretation on Osi and Marsegu Islands) } \\
\text { Ecotourism Facility Block (Osi island and Pelita Jaya Village) }\end{array}$ \\
\hline 2 & $\begin{array}{l}\text { Participation and empowerment of } \\
\text { coastal communities }\end{array}$ & $\begin{array}{l}\text { Building economic units (Cooperative) } \\
\text { Formation of business and aware tourists group } \\
\text { Entrepreneurship training (culinary, souvenirs, etc) } \\
\text { Training on seaweed cultivation and coral transplantation } \\
\text { Assistance for business actors } \\
\text { Determination of tourist villages }\end{array}$ \\
\hline 3 & $\begin{array}{l}\text { Partnership among stakeholders in the } \\
\text { effort to manage attractions, amenities, } \\
\text { and accessibility }\end{array}$ & $\begin{array}{l}\text { Strengthening cooperation and coordination among stakeholders } \\
\text { Developing promotion of natural resource potential in the Kotania Bay continuously } \\
\text { through printed and electronic media, by all stakeholders involved } \\
\text { Implement a "collaborative management" model }\end{array}$ \\
\hline 4 & $\begin{array}{l}\text { Conservation, socialization, and } \\
\text { education }\end{array}$ & $\begin{array}{l}\text { Socialization of the concepts of ecotourism and environmental conservation } \\
\text { Establish the area as a research location } \\
\text { Establish areas or spots for the protection and preservation of coral reefs } \\
\text { Encourage the participation of local communities and stakeholders in } \\
\text { environmentally friendly activities }\end{array}$ \\
\hline 5 & $\begin{array}{l}\text { Improve supervision and law } \\
\text { enforcement }\end{array}$ & $\begin{array}{l}\text { Socialization of the rule of law regarding tourism and the environment } \\
\text { Conducting patrol activities continuously in the Kotania Bay } \\
\text { Strengthening traditional institutions in the supervision of ecotourism areas in the } \\
\text { Kotania Bay } \\
\text { Establish regulations related to the development of ecotourism in the village (Village } \\
\text { Regulation) }\end{array}$ \\
\hline
\end{tabular}

Table 5 showed that the partnership factors among stakeholders, i.e. the promotion of ecotourism programs and conservation education as well as intensive supervision from various parties are the next priorities that support the first and second priorities, so that they become a unity for the realization of the concept of sustainable ecotourism. Rhormens et al. (2017) reported that sustainable environmental monitoring and partnership factors are important principles in the management of an ecotourism area. This is following the principle of sustainable ecotourism is the sustainability of ecological, sociocultural, economic aspects and presenting educational values to the tourism products offered (Triyuniarthi 2010).

In conclusion, the potential of coastal and marine resources in Kotania Bay has the opportunity to be developed for marine ecotourism activities by implementing a diversification strategy (ST). A diversification strategy is a strategy that utilizes strengths and minimizes threats. This strategy is implemented with priority activities as follows: (i) developing potential of coastal and marine resources sustainably, (ii) participation and empowerment of coastal communities, (iii) development of partnerships among stakeholders, (iv) conservation education for local communities, and (v) supervision of the area, with successive values are $24.1 \%$; $23.6 \% ; 22.9 \% ; 19.2 \%$; and $10.3 \%$.

\section{ACKNOWLEDGEMENTS}

The authors declare that this study has not received any funding, and categorized it as an independent study. All authors are asserted that this study is a personal collaboration among lecturers of Universitas Pattimura and Universitas Terbuka, and was carried out independently. We also acknowledge to the staff of the Department of Forestry, and Department of Biology, Universitas Pattimura, and staff of Biology Education Department, Faculty of Education and Teacher Training, Universitas Terbuka. The authors also thank the laboratory staff of the Deep Sea Research Center, Indonesian Institute of Sciences (LIPI) who helped in analyzing of marine condition of Kotania bay.

\section{REFERENCES}

Abdulhaji Y. 2016. The influence of attractions, accessibility, and facilities on the image of Tolire lake attraction in Ternate city. Jurnal Penelitian Humano 7 (2): 134-148. DOI: 10.33387/hjp.v7i2.317. [Indonesian]

Baiquni M. 2013. Geostrategy of Indonesia and pacific islands on ecotourism collaboration. In: Baiquni M, Damanik J, Rindrasih E (eds.). Ecotourism Destinations in Archipelago Countries. Gadjah Mada University Press, Yogyakarta. [Indonesian]

Burke L, Reytar K, Spalding M, Perry A. 2011. Reefs at Risk Revisited. World Resources Institute, Washington, DC.

Coria J, Calfucura E. 2012. Ecotourism and the development of indigenous communities: The good, the bad, and the ugly. Ecol Econ 73 (15): 47-55. DOI: 10.1016/j.ecolecon.2011.10.024. 
Damanik J, Weber HF. 2006. Ecotourism Planning (from Theory to Applications). Andi Publisher, Yogyakarta. [Indonesian]

Damanik J. 2013. Social and cultural dimensions of ecotourism development in small island. In: Baiquni M, Damanik J, Rindrasih E (eds.). Ecotourism Destinations in Archipelago Countries. Gadjah Mada University Press, Yogyakarta, Indonesia. [Indonesian]

Das M, Chatterjee B. 2015. Ecotourism: A panacea or a predicament? Tourism Manag Perspec 14: 3-16. DOI: 10.1016/j.tmp.2015.01.002

Emmanuel K, Spence B. 2009. Climate change implications for water resource management in Caribbean tourism. Worldwide Hospitality and Tourism Themes 1 (3): 252-268. DOI: 10.1108/17554210910980594.

English S, Wilkinson C, Baker V. 1997. Survey Manual for Tropical Marine Resources. Australian Institut of Marine Science, Townsville.

Fandeli C, Muhamad. 2009. Basic Principles for Conserving Landscapes. Gadjah Mada University Press, Yogyakarta, Indonesia. [Indonesian]

Ghorbani A, Raufirad V, Rafiaani P, Azadi H. 2015. Ecotourism sustainable development strategies using SWOT and QSPM model: A case study of Kaji Namakzar Wetland, South Khorasan Province, Iran. Tourism Manag Perspect 16: 290-297. DOI 10.1016/j.tmp.2015.09.005

Gunn CA. 1994. Tourism Planning: Basics, Concepts, Cases. Taylor and Francis Ltd, Washington DC.

Idajati H, Pamungkas A, Kukinul VS. 2016. The level of participation in mangrove ecotourism development, Wonorejo Surabaya. International Conference, Intelligent Planning Towards Smart Cities, CITIES, Surabaya. [Indonesian]

IUCN. 1994. Guidelines for protected areas management categories. IUCN Commissions on National Parks and Protected Areas (CNPPA)-World.

Latuconsina H. 2016. Tropical Aquatic Ecology. Gadjah Mada University Press, Yogyakarta, Indonesia.

Lelloltery H, Pudyatmoko S, Fandeli C, Baiquni M. 2018a. Study of coral reef for marine ecotourism development based on region suitability and carrying capacity in Marsegu Island Nature Tourism Park, Maluku, Indonesia. Biodiversitas 19 (3): 1089-1096. DOI: 10.13057/biodiv/d190342

Lelloltery H, Pudyatmoko S, Fandeli C, Baiquni. 2016. Development of ecotourism based on conformity and carrying capacity of coastal areas (case study of Marsegu Island) Western Seram Regency. J Agric Cultivation 12 (1): 25-33.

Lelloltery H, Pudyatmoko S, Fandeli C, Baiquni. 2018b. Socio-economic study of the community and the role of stakeholders in ecotourism development in Marsegu island natural tourism park, Western Seram Regency. J Trop For 3: 302-314.
Nikijuluw VPH. 2003. Aspek Sosial Ekonomi Masyarakat Pesisir dan Strategi Pemberdayaan Mereka dalam Konteks Pengelolaan Sumberdaya Pesisir Secara Terpadu. In: Knight M, Tighe S (eds) Koleksi Dokumen Proyek Pesisir 1997-2003. Coastal Resources Center, University of Rhode Island, Narragansett, Rhode Island, USA.

Rangkuti F. 2002. Analisis SWOT Teknik Membedah Kasus Bisnis. Gramedia Pustaka Utama, Jakarta. [Indonesian]

Reihanian A, Mahmood NZB, Kahrom E, Hin TW. 2012. Sustainable tourism development strategy by SWOT analysis: Boujagh National Park, Iran. Tourism Manag Perspect 4: 223-228. DOI: 10.1016/j.tmp.2012.08.005.

Rhormens MS, Pedrini AG, Lopes NPG. 2017. Implementation feasibility of a marine ecotourism product on the reef environments of the marine protected areas of Tinhare and Boipeba Islands (Cairu, Bahia, Brazil). Ocean Coast Manag 139: 1-11. DOI: 10.1016/j.ocecoaman.2017.01.022.

Rhormens MS, Pedrini AG, Lopes NPG. 2017. Implementation feasibility of a marine ecotourism product on the reef environments of the marine protected areas of Tinhare and Boipeba islands (Cairu, Bahia, Brazil). Ocean Coastal Manag 139: 1-11. DOI: 10.1016/j.ocecoaman.2017.01.022.

Saaty TL. 1993. Decision making for leaders: analytic hierarchy process for decision making in complex situations. Binaman Presindo, Jakarta, Indonesia. [Indonesian]

Stronza A, Gordillo J. 2008. Community views of ecotourism. Ann Tourism Res 35 (2): 448-468. DOI: 10.1016/j.annals.2008.01.002

Supriharyono. 2007. Konservasi Ekosistem Sumberdaya Hayati di Wilayah Pesisir dan Laut Tropis. Pustaka Pelajar, Yogyakarta. [Indonesian]

Triyuniarthi. 2010. The Concept of Marine Ecotourism with The Approach of Developing Sustainable Tourism Products on Lelei island, Guraici Archipelago, Southern Halmahera Regency, North Maluku. [Thesis] Universitas Gadjah Mada, Yogyakarta. [Indonesian]

Wabnitz CCC, Montemayor AMC, Hanich Q, Ota Y. 2017. Ecotourism, climate change and reef fish consumption in Palau: Benefits, Tradeoffs and adaptation strategies. Mar Policy 88, 323-332. DOI: 10.1016/j.marpol.2017.07.022.

Walters RDM, Samways MJ. 2001. Sustainable dive ecotourism on a South African coral reef. Biodivers Conserv 10 (12): 2167-2179. DOI: $10.1023 / \mathrm{A}: 1013197926580$.

Yulianda F. 2007. Ekowisata bahari sebagai alternatif pemanfaatan sumberdaya pesisir berbasis konservasi. Makalah Seminar Sains 21. [Indonesian] 